\title{
Intertheatrical Cues and Shakespearean backstories
}

\author{
William E. Engel
}

\section{(2) OpenEdition \\ Journals}

\section{Electronic version}

URL: https://journals.openedition.org/shakespeare/6199

DOI: 10.4000/shakespeare.6199

ISSN: 2271-6424

\section{Publisher}

Société Française Shakespeare

\section{Electronic reference}

William E. Engel, "Intertheatrical Cues and Shakespearean backstories", Actes des congrès de la Société française Shakespeare [Online], 39 | 2021, Online since 21 June 2021, connection on 23 August 2021 URL: http://journals.openedition.org/shakespeare/6199; DOI: https://doi.org/10.4000/shakespeare. 6199

This text was automatically generated on 23 August 2021.

(c) SFS 


\title{
Intertheatrical Cues and Shakespearean backstories
}

\author{
William E. Engel
}

The memory of a given reading is a representation, and only a representation; it is embraced in an intuition of the mind which I may lengthen or shorten at will; I assign to it any duration I please; there is nothing to prevent my grasping the whole of it instantaneously, as in one picture. -Henri Bergson ${ }^{1}$

\section{The tug of memory, staging recollection, and pattern completion}

1 Building on my previous work on pattern recognition with reference to the early modern afterlife of the classical Art of Memory, ${ }^{2}$ this essay expands the field of inquiry to focus on Shakespeare. I do so with the goal of offering a way of understanding, in the dynamics of their reception, Shakespeare's well-placed allusions designed to trigger otherwise concealed moments in a character's backstory. Such moments provide a context for assessing what lies behind the on-stage action. Let me begin by clarifying three closely linked themes that guide my investigation. First, I will explain what is meant by "the tug of memory," for this is the through-thread of my ensuing analysis of representative scenes from Shakespeare. Second, I will indicate how some specific conceptual terms taken from early modern rhetoric and contemporary memory studies concerning recollection and pattern completion can be used to advance my examination. Third, I will outline how the tug of memory participates in those commonplace rhetorical tactics fundamental to humanist educational practices in England during Shakespeare's day (a theme developed in greater detail in sections two and three).

2 Shakespeare's use of what I am calling the tug of memory is never in vain; it is a quick or sharp pull, ${ }^{3}$ in this case at something seemingly recessed or half-forgotten which, in a snap, is brought to the audience's attention. The word "tug" etymologically derives from an Old High German verb for "jerk" or "draw quickly," and by the sixteenth century denoted any sudden or powerful pull. ${ }^{4}$ As with the classical Art of Memory, 
where images are stored in sequence for easy recollection and application, ${ }^{5}$ I am using the tug of memory to describe Shakespeare's presentation of a verbal cue to activate on stage the memory of some past instance. Indeed, the concatenation of memory images in classical rhetorical sometimes was figured as dancers linked hand in hand, each pulling the other along. ${ }^{6}$ So too, I shall be arguing, this is the case with Shakespeare's activation of the tug of memory by means of which an articulated token of remembrance is both what initiates the tug and also is itself the thing that suddenly is being jerked into the spotlight. Audiences thus are made to remember something from a character's past, something that conveys telltale cues enabling a glimpse into the character's inner life. ${ }^{7}$ And the cue, qualified in my main title as being intertheatrical, ${ }^{8}$ initiates this sudden pull insofar as it is tethered to some memory or story that will, in short order, be brought into view. Although I am using "cue" principally in its rhetorical (and, more strictly speaking, mnemotechnical) sense throughout, the word likewise has a long history in the dramatic arts: actors are prompted-or cued-to say their lines based on what the actor before them has just said. Actors playing off one another's cues (a prerequisite for smooth and coherent performances), however, still brings us back, metaphorically at least, to Quintilian's hand-clasping dancers where each needs the other to make the whole choreography of the scene come together and work as an ensemble. Although cues in theatre and in rhetoric are not that far removed from one another, the word "cue" technically belongs to theatre and its importance as such should not be overlooked. ${ }^{9}$ The tug of memory cues the audience to become aware of some otherwise previously unseen connection that now is being made a part of the play.

3 Concerning the theme of recollection, as my epigraph from Henri Bergson intimates, modern cognitive theory and memory studies provide a vocabulary for comprehending what I aim to disclose about Shakespeare's use of such intertheatrical cues. Intertheatrical cues include props (whether skulls, letters, or handkerchiefs) ${ }^{10}$ as well as verbal and visual prompts, all used to trigger recall, as part of the normative stage business for advancing the plot while revealing something about the inner-life or secret designs of the characters involved. The audience takes in what amounts to succinctly packaged "recovered histories," a production feature William Dodd insightfully discusses in terms of "discourse biographies." ${ }^{11}$ And in cognitive science, episodic memories are those that typically comprise multiple elements, although a single element can be sufficient to prompt recollection of the whole event. This notion can help us analyze the impact of Shakespeare's incremental disclosure of a character's backstory in a play. A defining characteristic of episodic retrieval is "holistic recollection," the comprehensive recall of the elements a memorized event encompasses. ${ }^{12}$ With respect to the Shakespearean text, the staging of such holistic recollection is the result of mental activity involving the representation of an implied full event from one event element, known as "pattern completion." ${ }^{13}$ A good case in point illustrating the effect of pattern completion activated by a verbal cue, what I am calling the tug of memory, comes midway through The Merchant of Venice.$^{14}$ This brief episode signals a decisive turning point in the play's coloring of audience perception of the character's history which, up to this point, has been fairly two-dimensional and straightforward. It begins innocently enough, as a report to Shylock about his missing daughter, but suddenly and powerfully gives rise to a disclosure that brings into the open something otherwise unknowable to the audience and yet fundamental to the character's backstory. Jessica was seen in Genoa after having stolen away from her 
father's house in Venice with her Christian suitor, Lorenzo, and taken with her a portion of Shylock's treasure.

TUBAL. One of them showed me a ring that he had of your daughter for a monkey.

SHYLOCK. Out upon her! - thou torturest me Tubal, -it

was my turquoise; I had it of Leah when I was a

bachelor: I would not have given it for a wilderness of

monkeys. ${ }^{15}$

The Merchant of Venice, 3.1.110-115

In the staging of this terse, revelatory episode, the audience is impelled to entertain the notion - if only for a fraction of a second - of a flesh and blood shylock who has perhaps not always been so gruff. The subliminal activation of this recollected image of a kinder, gentler Shylock is all the more resonant because of its lack of specificity after all, it is someone's else's memory we are being asked to share. ${ }^{16}$ In the blink of the mind's eye, we catch a glimpse of young shylock courting and perhaps even doting on the woman who would become his wife and Jessica's mother, Leah, otherwise absent from the play. This is a side of the moneylender the audience has not previously been given reason to consider. Moreover, its eruption on the stage at this point gives palpable credence to Shylock's rhetorically amplified expostulation earlier in the same scene to Salarino and Solanio, friends of the merchant Antonio (two seemingly interchangeable factotum characters, the "Rosencrantz and Guildenstern" of this play).

SHYLOCK: Hath not a Jew eyes?

hath not a Jew hands, organs, dimensions, senses,

affections, passions? fed with the same food, hurt with

the same weapons, subject to the same diseases, healed

by the same means, warmed and cooled by the same

winter and summer, as a Christian is?

MV, 3.1.54-59

5 This declaration both corroborates that Shylock indeed does have affections and passions, and imbues the ring he had of Leah with a special kind of mnemotechnic potency. Further, as will be discussed in section two, such mnemonic pattern completion was part and parcel of the early modern commonplace book method of study and composition. Erasmus, for example, explicitly recognized adages as an aidemémoire, contending that in the proverb "almost all the philosophy of the Ancients was contained." ${ }^{17}$ His encyclopedic exposition of the proverb, which became a part of practical schoolroom exercises in Renaissance England, ${ }^{18}$ underwrites some key moments in Shakespeare's plays whereby we can see the extent to which such episodic memories bind multiple elements into a single representation. Holistic recollection, according to findings in cognitive theory, is tantamount to the comprehensive recall of the elements that an event encompasses even though seemingly incidental to the current situation, ${ }^{19}$ like the reference to Shylock's turquoise and all it conjures up. The cue information needs to be completed with reference to the full event to produce comprehensive recall. ${ }^{20}$ Pattern completion happens when we take one or a few details and use them to construct a complete memory. By means of a few choice words, Shakespeare thus sets in motion the recollection of some event or action in the past so that the audience now can factor this in with their judgment of the character. The resulting and instantaneous cognitive experience involves a dramaturgical parallax, or alternating perspective, that bespeaks a displacement or difference in the apparent position of the subjects narrating their own histories, viewed along two different, 
temporally conditioned, lines of sight. Specifically, the proleptic statements of the characters looking back to relate aspects of their backstories serve to make the past viscerally and emotionally present. Shakespeare's cueing up of such moments sets memory to work, tugging at what is to be recalled, suddenly yanking it from the past into the present.

\section{Abbreviation and amplification in the context Renaissance rhetorical practices}

6 The boundary between the stage and lived experience materializes, as it were, with evocations of the backstories of Shakespeare's characters. One of the ways the playwright sets up if only to skirt this boundary is by tapping into episodic memories that bind multiple elements into a single representation. As discussed in section one, this is what is implied by the tug of memory and is realized through presenting cue information about an event element, whether distilled and compact or expansive and dilative. During the English literary Renaissance these approaches to handling such cue information were expressed as and by means of rhetorical figures that, according to George Puttenham, were recognized as abbreviation - exemplified through the figure of paremia (deploying "some common proverb or adage") - and "copious amplification." ${ }^{21}$ They functioned as the twin poles of narrative description, with a lineage going back to Aristotle; ${ }^{22}$ elaborated with respect to oratory by Cicero and Quintilian; ${ }^{23}$ kept alive during the Middle Ages especially by Geoffrey of Vinsauf; ${ }^{24}$ and further codified and catalogued in the Renaissance principally by Erasmus. ${ }^{25}$ For Shakespeare as for other contemporary playwrights, amplification and abbreviation, or dilation and contraction as they sometimes were known in Renaissance rhetorical handbooks, ${ }^{26}$ were the main modalities of copious expression - or copia. ${ }^{27}$ The goal of copia was to cultivate a fulsome style through accumulating and having ready access to an abundant and expansive stock and store for amplifying and augmenting one's speech and writing.

7 Allusions to these figures with reference to various types of narrative ploys, including tapping into the backlog of historical anecdotes and excerpting famous sayings from classical texts, were fundamental to the pedagogical practices in sixteenth century England. ${ }^{28}$ Two sides of the same rhetorical coin, these tropes of abbreviation and amplification are put on display - and, to some extent, slyly subverted - with exuberant transparency in Henry $V$, as will be disclosed more fully in section three. As a preliminary case in point though, to introduce how these tropes of copia operate (amplification and abbreviation respectively), let me mention two closely related moments in Henry $V$ that speak directly to this theme. The first is the use of exempla (famous deeds of the ancients from which moral lessons were to be derived) on the part of the English camp, most notably Fluellen, where recollected precedents and celebrated champions of warfare serve as the mnemic seeds of history, associated in Renaissance faculty psychology with memory. ${ }^{29}$ And the second, on the part of the French camp, we observe the marshaling of proverbs and sententiae (the sayings - or saws - often derived from ancient sources), ${ }^{30}$ those pithy constituent elements of moral philosophy. ${ }^{31}$

8 With respect to the first, the bombastic Fluellen (Shakespeare's fictive Welsh captain leading a contingent of troops in Henry's campaign in France during the Hundred 
Years' War), appears to be an avid if somewhat inattentive reader of deeds and sayings of ancient worthies. And, as was the case with many new readers of increasingly accessible humanist works of the day, Fluellen typifies the casual peruser of ancient texts - or, more likely, of epitomes and anthologies - cherry-picking salient details to argue his point..$^{32}$ This was the aim of keeping a commonplace book (whether based on one's own reading, ${ }^{33}$ or in pre-digested print form) filled with memorable entries so one might be stirred to recall what they referred to and be able to expand on any given theme amplified copiously with references to choice classical works.

FLUELLEN. I think it is in Macedon where Alexander is porn. ${ }^{34}$

I tell you, Captain, if you look in the maps of the

world, I warrant you shall find, in the comparisons

between Macedon and Monmouth, that the situations,

look you, is both alike. There is a river in

Macedon, and there is also moreover a river at

Monmouth. It is called Wye at Monmout, but it is

out of my prains what is the name of the other

river; but 'tis all one, 'tis alike as my fingers is

to my fingers, and there is salmons in both. If you

mark Alexander's life well, Harry of Monmouth's life

is come after it indifferent well, for there is

figures in all things. Alexander, God knows, and

you know, in his rages, and his furies, and his

wraths, and his cholers, and his moods, and his

displeasures, and his indignations, and also being a

little intoxicates in his prains, did, in his ales and

his angers, look you, kill his best friend, Cleytus.

GOWER. Our king is not like him in that: he never killed

any of his friends.

FLUELLEN. It is not well done, mark you now, take the tales out

of my mouth ere it is made an end and finished. I speak

but in the figures and comparisons of it. As

Alexander killed his friend Clytus, being in his

ales and his cups, so also Harry Monmouth, being in

his right wits and his good judgements, turned away

the fat knight with the great-belly doublet: he

was full of jests, and gipes, and knaveries, and

mocks; I have forgot his name. ${ }^{35}$

H5, 4.7.22-49

Looking back to the exemplars of the past, Fluellen inadvertently makes a hash of the rhetorical tropes reserved for augmentation. His main talking point concerns establishing an analogy that parallels young Harry of Monmouth (Henry V) to Alexander the Great, and Falstaff to Clytus. Far from making this point though, what is highlighted here is how his fumbled allusion extends but does not illuminate the topic.

Fluellen's failed tactic of amplification is given its own parallel in the French camp albeit from the other end of the copiousness spectrum, namely abbreviation, with the marshaling of proverbs and sententiae by the Dauphine and his captains (discussed at length in section three). Shakespeare showcases the extent to which recourse to copiousness in this game of one-upmanship is virtually inexhaustible - and hence potentially exhausting for the audience. The playwright tests just how long the jest can be sustained and still remain entertaining, while at the same time holding this kind of display up to ridicule as an indecorous display of copia. In this excerpt we see a breakdown in the signifying power of the proverb, which ordinarily would be sufficient 
in and of itself to convey is meaning owing to its transparent, generally understood meaning. In fact, though, each proverb is countered by another, resulting in a ridiculous exchange devoid of any real meaning other than to reveal the contentious nature of the characters engaged in such foolish banter, using adages that are supposed to be compact receptacles of universal if commonplace wisdom. ${ }^{36}$ The larger implication, of course, is that there is such an enormous reservoir of proverbial wisdom that when deployed ad absurdum there is no end to what could be constructed.

CONSTABLE. By my faith, sir, but it is: never anybody

saw it but his lackey. 'Tis a hooded valour; and when it

appears, it will bate.

ORLEANS. 'Ill will never said well.'

CONSTABLE. I will cap that proverb with 'There is flattery in friendship.'

ORLEANS. And I will take up that with 'Give the devil his due.'

CONSTABLE. Well placed: there stands your friend for

the devil. Have at the very eye of that proverb with 'A

pox of the devil.'

ORLEANS. You are the better at proverbs by how much

'A fool's bolt is soon shot.'

CONSTABLE. You have shot over.

ORLEANS. 'Tis not the first time you were overshot.

Enter a Messenger.

H5, 3.7.112-126

Presumably this banter in proverbs could have gone on for a while longer but conveniently is cut off mid-quip by the entrance of a messenger who reports the English vanguard is within fifteen hundred paces.

As will be discussed in what follows, Shakespeare's self-conscious use of these tropes of abbreviation and amplification reflects fairly standard rhetorical and textual habits of the period. And yet, the ways these tropes end up being expressed by his characters given what is intimated about their own implied histories - mark them as being productively recursive. The episode in Henry $V$ (3.7) referenced above offers a representative test case indicating a preferred dramaturgical practice by means of which the identity of a character is constructed in terms of, and also is conditioned by, these telltale figures of speech in the Shakespearean text.

\section{Drawing out latent readings and "hypodiegetic memory"}

This much having been observed it is appropriate, at the midpoint of this investigation, to pause and consider what exactly is meant when we speak of "the Shakespearean text" as such. The usual meaning is "the text as it has come down to us" through extant and variant copies, conditioned by sometimes tangled concatenations of editorial transmission practices each replete with a contested history of its own. ${ }^{37}$ Accordingly, then, the Shakespearean playscript can be thought of as a trace. And more specifically as regards this present investigation, it can be thought of as a conjectural record of how various mnemotechnical cues from within the text might be played out in performance. As Eric Griffiths has pointed out in his discussion of the First Quarto of Hamlet and its later editors, "we cannot have a text of Shakespeare's at all without such an exercise in imagination. For the meaning of the words on the page does not declare itself, nor is it separable from features of voicing." ${ }^{38}$ Extra means are required to make 
an actor's reading text clear because the written text is knotted with ambiguities, often lacking the cues of speech, such as tone, gesture, and facial expression. Shakespeare's plays are packed with many such instances of latent, possible readings. And, as if anticipating just such a concern, the playwright provides a tactical solution, the tug of memory (introduced and discussed in the first two sections). Included in the text are a class of allusive rhetorical cues that provide for such lines to be delivered with the aim of evoking a backstory that plausibly motivates the intertheatrical stage business at hand. ${ }^{39}$

14 The playwright provides and rewards the audience with access to a cache of assumed specific memories to be recalled concerning an event or series of contingent events preceding the temporal coordinates of the play. The abbreviated sharp tug of memory features significantly in Shakespeare's plays, whether Pompey's tethered bitter memory that Antony still has his "father's house," which he cannot help bringing up even as they toast a prospective alliance, "But what? We are friends!" (Antony and Cleopatra, 2.7.128-29); or in Beatrice's reminder to Benedick that they have a shared history such that she is aware of his tricks, "I know you of old" (Much Ado About Nothing, 1.1.139). With respect to this last example, the battle of wit between Beatrice and Benedick uses some of the same rhetorical quibbles found elsewhere in the canon, and especially in Henry V (3.7), most notably the jest about eating all one kills. ${ }^{40}$

DAUPHIN. 'Tis midnight; I'll go arm myself. [Exit]

ORLEANS: The Dauphin longs for morning.

RAMBURES: He longs to eat the English.

CONSTABLE: I think he will eat all he kills.

H5 , 3.7.91-94

The implication, of course, is that the Dauphin will not have to eat any. The same holds for Beatrice's mocking of Benedick's martial prowess: "But how many hath he killed? For indeed I promised to eat all of his killing" (Ado, 1.1.42). This recycled joke, while common in the period, ${ }^{41}$ was deployed in these two instances as a kind of quick character sketch of Benedick and the Dauphine as blustering swaggerers. As such it suggests something of the same underlying eristic structure in both of these contests of proverb-grounded wit that momentarily takes center stage in both plays, Much Ado and Henry $V$ respectively. Whereas the Constable of France genuinely thinks the Dauphin will not distinguish himself in battle (even though will not say this to his face, the Dauphin has just exited); Beatrice makes a public declaration of her spirited taunting of Benedick such that her uncle, Leonato, qualifies her quip: "You must not, sir, mistake my niece. There is a kind of merry war between Signor Benedick and her: they never meet but there's a skirmish of wit between them (Ado, 1.1.58-61). Here the backstory of a kind of needling amity ("merry war") between Beatrice and Benedick is corroborated. Moreover, the word "skirmish" evokes a sense of the martial implications of the proverbial battle of the sexes played out in Much Ado and which, in the end, will flip to embrace the marital sense as well. Comparably but in reverse in Henry $V$ the amorous discourse that is associated with sonnets and erotic blazons sets the scene for the French warriors' rhetorical wrangling, launched by the Dauphin's absurd encomium on his warhorse:

DAUPHIN. What a long night is this! I will not change my

horse with any that treads but on four pasterns. Ch, ha!

He bounds from the earth, as if his entrails were hairs -

le cheval volant, the Pegasus, qui a les narines de feu!

When I bestride him, I soar, I am a hawk. He trots the 
air. The earth sings when he touches it; the basest

horn of his hoof is more musical than the pipe of Hermes.

[...]

CONSTABLE. Indeed, my lord, it is a most absolute and

excellent horse.

DAUPHIN. It is the prince of palfreys; his neigh is like the

bidding of a monarch and his countenance enforces homage.

ORLEANS. No more, cousin.

DAUPHIN. Nay, the man hath no wit that cannot, from

the rising of the lark to the lodging of the lamb, vary

deserved praise on my palfrey. It is a theme as fluent

as the sea. Turn the sands into eloquent tongues, and

my horse is argument for them all. 'Tis a subject for a

sovereign to reason on, and for a sovereign's sovereign

to ride on, and for the world, familiar to us and

unknown, to lay apart their particular functions and

wonder at him. I once writ a sonnet in his praise and

began thus: 'Wonder of nature!'

ORLEANS: I have heard a sonnet begin so to one's

mistress.

DAUPHIN: Then did they imitate that which I composed

to my courser, for my horse is my mistress.

ORLEANS: Your mistress bears well.

H5, 3.7.11-45

This extended display of rhetorical self-consciousness reflects more than just the Dauphin's shallow character as someone still stuck in schoolboy mode, taking pride in his application of commonplace rhetorical exercises: "It is a theme as fluent as the sea. Turn the sands into eloquent tongues." Also disclosed here, in a nutshell, is what Shakespeare wants the audience to think about the flower of French chivalry, represented as a rout of contentious, bickering backbiters. Moreover, the allusive recollection of a poem that the Dauphin once wrote to his horse (which he seems ready to recite), exemplifies precisely the kind of tug of memory that Shakespeare activates time and again in his playtexts. He does so with the aim of getting the audience to call to mind some presumed general circumstances surrounding a speaker's character that is revealed through a telling moment recalled from (in this particular case) his past that leads to our still being able to conjure up the idea - if not the specifics - of just such a blazon. So yes, the Dauphin is a fop; but further, the sociable if eristic setting and the timely disclosure of this anecdote assures that a much more richly evocative and fully fleshed out backstory emerges.

The tug of memory is hypodiegetic, which is to say concerning an implied story within the given narrative that propels the reader or audience "under" or "beneath" the plot arc (as the Greek prefix hypo connotes; and diegesis means "a narrative"). Such hypodiegetic moments of implicit recall set in train a kind of secondary narrative upon which the current or primary one tacitly depends; something not fully disclosed though inferable from the interaction of the characters that subtly signals their present dealings are based on some previously shared experience now, quite expressly, brought back to mind. Audience awareness of this extra narrative level is facilitated dramaturgically through a well-marked and duly noted tug of memory. While the audience cannot (and indeed need not) know all the details involved, we recognize the tug of memory along with and at the same time as the characters who are being thus reminded; and, we respond by imagining the conjectural hypodiegetic memory - 
namely, a memory preceding, conditioning, and constituent of the world of the play with special reference to a submerged narrative that we have been bidden to call to mind. It is by such means that pattern completion can be achieved, and the play proceed.

Shakespeare's ingenious pastiche of proverbs in Henry $V$ (3.7.112-126) constructs and delivers a backstory of mutual antagonism among leaders of the French camp at Agincourt by means of the humanist recreational exercising of wit through copia. Hence, within the world of the play, the present is shown to be informed by actions and discernible behavioral patterns collected from the past. These brief reminders, by way of ostensible "throwaway lines," are in fact dramaturgically expedient triggers for the recall of key elements in characters' backstories otherwise inaccessible to the audience. Without these triggers, no holistic recollection can emerge. To use another example, in final moments of Hamlet, Fortinbras declares to the remnant of the Danish court that he has "some rights of memory in this kingdom, / which now to claim my vantage doth invite me" (Ham., 5.2.396-397); a declaration that bookends and recalls the preparatory corroborative information Horatio disclosed in the opening scene about "the inheritance of Fortinbras" (Ham., 1.1.95). ${ }^{42}$ This sets up a more fully fleshed out and politically nuanced backstory that impels the audience to imagine and entertain a whole submerged history, one that turns out to be fundamental to the main dynastic plot, and one that is being dragged along implacably - or tugged - by memory. This careful cueing of episodic memory both anticipates and delivers pattern completion, whether or not one ultimately is satisfied with the way things turn out.

\section{The emblematic significance of proverbs and the plotting of Shakespearean backstories}

The early modern context of this mnemotechnically inflected approach to restoring relevant if seemingly half-forgotten bits of knowledge can be brought into sharper focus with the example of Francis Meres. He recorded the following adage, placed under the topical heading of "memory," in what amounts to a published commonplace book: "Little fishes slip through nets, but great fishes are taken; so small things slip out of memory, when as great matters stay still." 43 This adage touches on a matter of great concern to pragmatic humanists of the day; namely the preservation and retention of even small matters, the details, things likely to be forgotten along the way or overshadowed by larger concerns. By way of remediating this situation, Renaissance writers had recourse to commonplace rhetorical techniques grounded in place-system mnemonics. Specifically, local memory systems gave a ready way to engage actively in the invention of backgrounds (loci or places) and to fix and arrange lively images in a sequential order of some sort conducive to easy recall and later use. ${ }^{44}$

This proverb about little fishes and the net of memory is attributed to Erasmus in Meres's anthology; and, as such, attests to its easy portability and rich afterlife in printed sources, which further guaranteed the circulation of what was judged to be an effective, because memorable, adage. We are afforded here a glimpse into the cultural work of the early modern tactic of collocation. ${ }^{45}$ Collocation simply is the placing of things side by side for later consideration and, in Shakespeare's case (exemplarily in Henry $V$, 3.7), for cueing resonant evocations of specific elements in an allusive backstory. Drawing on a backlog of collocated material for one's own use - whether in 
written work, table talk, extemporaneous speeches, or playscripts - was (as previously observed in section one) part and parcel of the rhetorical training of the age. Erasmus formalized on a larger scale what others already were doing, and which Francis Bacon endorsed: "For the disposition and collocation of that knowledge which we preserve in writing, it consisteth in a good digest of common-places." ${ }^{46}$ Meres was publishing for a new generation of readers, fifty years after the boom of translations of Erasmus's textbooks; for there was a discernible "surge in English collections based on Erasmus's works" which can be attributed partly "to the gradual introduction of the new standards set by the humanist educational agenda" coincident with "the introduction of Erasmus' proverb collections in the curriculum." 47

21 The trade in proverbs was a pervasive feature of Renaissance literary and mnemonic culture. Erasmus launches his Adages with several ancient definitions and, at length, offers his own: "A proverb is a saying in popular use, remarkable for some shrewd and novel turn." ${ }^{48}$ The universally acclaimed practice of copia was described with care by Erasmus in the opening chapter of his book on the subject. Typical of his pedagogy, he models in his writing the virtues he would have his students attain by inserting a wellplaced proverb to fix this very theme in the his readers' memory. Erasmus proactively admonishes his readers about what should be kept in mind while using his handbook, On Copia of Words and Ideas: "For as there is nothing more admirable or more splendid than a speech with a rich copia of thoughts and words overflowing in a golden stream, so it is, assuredly, such a thing as may be striven for at no slight risk, because according to the proverb, 'Not every man has the luck to go to Corinth." ${ }_{49} \mathrm{He}$ does not gloss the origin of this proverb about everyone not having the same opportunities or access to sources of classical information. An already learned reader, one who proverbially had been to Corinth, would have known it comes from Horace's Epistles (1.17.36) and is echoed in Aulus Gellius's Attic Nights (1.8.4). But more to the point, as is well known, most of the ancient writers Erasmus quoted as illustrations come from Quintilian rather than directly from the original authors. This is not to take anything away from his achievement, but to put it in context. The same applies to Shakespeare's lining up of proverbs (H5, 3.7.65-126), most of which are identified by editors simply as "traditional" with a nod to Tilley's dictionary, ${ }^{50}$ for what in fact we find here is a special kind of ingenuity when it comes to activating the hypodiegetic tug of memory.

Henry V (3.7) presents a concentrated and stunning display of proverbs mobilized as topoi, as memorable places of invention, set in the French camp during the restless night before the Battle of Agincourt. As already observed in section three, it is touched off by the Dauphin's encomium to his horse in terms properly reserved for the praising of one's lady. His extravagant use of copia recalls an Erasmian catalogue of periphrasis. ${ }^{51}$ Rather than deploying the usual terms of forensic oratory to score their points, the case is debated in proverbs, punctuated by a series of sporting double entrendres and jibes involving the visual lexicon of heraldry.

RAMBURES: My Lord Constable, the armour that I saw

in your tent tonight, are those stars or suns upon it?

CONSTABLE. Stars, my lord.

DAUPHIN. Some of them will fall to-morrow, I hope.

CONSTABLE. And yet my sky shall not want.

DAUPHIN. That may be, for you bear a many

superfluously, and 'twere more honour some were

away.

H5, 3.7.70-77 
this easy commerce of rhetorical blazons, heraldic cant, and pointed proverbs to which I would direct our attention. Each of these figures of speech, tropes, and features of copiousness are used by the speakers seemingly aware that these are the constituent parts of an argument insofar as they comment on them as such. Each one takes us back to a cache of some prior repository, making a claim on memory - and wit.

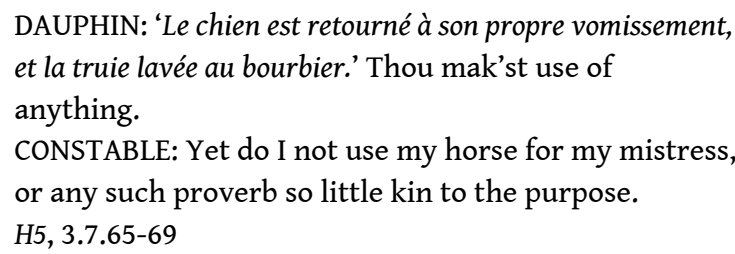

of the many things one might say about this remarkable exchange, Shakespeare's Dauphin quotes from the vernacular French Huguenot version of the scriptural warning to backsliders, concerning the dog returning to its vomit and a washed pig to its mud (Proverbs 26:11, cf. 2 Peter 2:22). ${ }^{52}$ What stands out most though is that the cited proverb comes from the Ur-text of proverbially framed wisdom, namely the biblical book of Proverbs attributed to wise King Solomon.

Here, more directly than in the other points scored in this otherwise fairly typical display of the combative schoolroom exercise known as contentio, ${ }^{53}$ we catch a glimpse of how proverbs are enlisted in the service of one's argument, smuggled into one's discourse. This applies especially to the rapid-fire matching of proverb for proverb at the end of this episode which, like the whole passage, is a staged representation of the kind of everyday repartee one might use in conversation, composed out of the mnemonically grounded germs of experience distilled from and associated with proverbs. Moreover, the metacritical proverb from the scriptural book of Proverbs is cast in French, even as is the Dauphin's initial praise for his warhorse (quoted in section three). This allusive reference to Proverbs is one of several key moments in the play where the French language figures significantly. Others include Princess Katherine's English "language lesson" on her body parts (3.4), swaggering Pistol's quibbling with his prisoner over a fit ransom (4.4), and Henry's hilariously embarrassing schoolboy "false French" in his marriage proposal (5.2). ${ }^{54}$

As with the adage of the fish and the net, the audience may not long remember the specific details of this witty barrage of proverbs (3.7.112-126) but will leave the episode with an indelible impression of the French as commonplace-dependent combatants, ridiculous in their feisty posturing. The audience furthermore is left with a sense of admiration at the handling of this witty and densely packed rhetorical display; for admiration, after all, was the nominal theme setting off the whole exchange, albeit concerning a horse. We admire in this scene how pliant such shopworn tropes and proverbs actually are - or can be - when ingeniously deployed. These quips, and their swift overturning, are drawn from a well-stocked reservoir of commonplaces shared by characters and audience alike. This is why the proverbs, with their universal resonance, also have the power to convey the tense humor of a battle of wit prior to an actual historical battle memorialized in this play (which the audience knows was disastrous for the French). These deftly managed commonplaces thus induce the audience to recall and reflect on the mnemotechnical operations to which all such collocated proverbs owe their origin. 
27 I have gone on at length about the Renaissance mentalité associated with collocation and the commonplace book method because, as the long passage in Henry $V$ (3.7) exemplifies, it offers critical insight into an early modern view of the present as being saturated with and animated by the words, actions, and patterns of intellectual behavior from the past. Churned up in its wake we discover, at the same moment as do the characters in the play, something we've been called on to remember, drawing up from oblivescence the proverbial net full of fishes which now has been brought centerstage.

Future study along these lines can help clarify further what is at stake in such particularized stagings of the tug of memory through spoken directives to recall things preceding the chronology of the play, especially as regards the classical rhetorical principles of inventio (the discovery of arguments) and memoria (the treasury of things invented). Regarding the latter, for example in Cymbeline, Iacomo's report back in Rome, based on his fabricated domus locorum (his memory theatre initially "noted" in his table book but ultimately, he reflects, ensconced in his memory) of which Imogen constitutes the central image (Cym. 2.2.43-44), is a collocation of memory images and suggestively urged associations that cause the narrative to fold back on itself in order to move the plot forward (Cym., 2.4.68-90)..$^{55}$ By such means the audience is primed to gain access to a hypodiegetic "memory picture," much in the same way as emblems, collocated commonplaces, and other mnemotechnical schemes enable one to invent and retain whole histories for future recollection and use. Such is the powerful tug of memory in the on-stage disclosure of Shakespeare's allusively proleptic backstories. By virtue of attending carefully to mnemotechnical cues and dramaturgically motivated declamatory cues that conjure up plausible backstories leading to incipient action in the world of the play, this study has sought to offer a useful heuristic design for anyone who would move the Shakespearean text from page to stage.

\section{NOTES}

1. Henri Bergson, Matter and Memory, trans. Nancy Margaret Paul and W. Scott Palmer, London, George Allen and Unwin, 1911, p. 91.

2. William E. Engel, Early Modern Poetics in Melville and Poe: Memory, Melancholy, and the Emblematic Tradition, New York, Routledge, 2016, p. 1.

3. OED, tug, definition 1.

4. Eg, "tugging forth" in Thomas Nashe, Lenten Stuff, London, Nicholas Ling, 1599 , sig. F1 ${ }^{\mathrm{v}}$, STC ( $2^{\text {nd }}$ ed.) 18370, last accessed (via EEBO) 8 July 2020.

5. Frances A. Yates, The Art of Memory, Chicago, University of Chicago Press, 2001, p. 12-26.

6. Quintilian, Institutio Oratoria (XI.2.20), trans. H. E. Butler, Cambridge, MA, Harvard University Press, 1979.

7. Some of the same concerns of my essay (regarding the ways Shakespeare's characters are lent complexity) are shared by Jelena Marelj, Shakespearean Character: Language in Performance, London, Arden Shakespeare, 2019; see especially the Introduction, "Re-Characterizing Shakespearean character." 
8. William West, "Intertheatricality," ed. Henry Turner, Early Modern Theatricality, Oxford, Oxford University Press, 2013, p. 151-172.

9. See especially in this regard, Simon Palfrey and Tiffany Stern, Shakespeare in Parts, Oxford, Oxford University Press, 2007, esp. part 2 "Interpreting Cues"; and Tiffany Stern, Documents of Performance in Early Modern England, Cambridge, Cambridge University Press, 2012, p. 8-35 on "plot-scenarios."

10. Cf. Lina Perkins Wilder, Shakespeare's Memory Theatre: Recollection, Properties, and Character, Cambridge, Cambridge University Press, 2010, p. 141-143

11. William Dodd, "Character as Dynamic Identity: From Fictional Interaction Script to Performance," ed. Paul Yachnin and Jessica Slights, Shakespeare and Character, New York, Palgrave Macmillan, 2009, 62-79, esp. p. 63-64.

12. Xenia Grande, David Berron, et al., "Holistic Recollection via Pattern Completion," Journal of Neuroscience 39.41, 2019, 8100-8111.

13. Idem.

14. All references to Shakespeare's plays follow The Arden Shakespeare, Complete Works, ed. Richard Proudfoot, Ann Thompson, and David Scott Kastan, rev. ed., London, Thompson Learning, 2001; hereafter cited parenthetically (using accepted play abbreviations given in the MLA Handbook, $8^{\text {th }}$ ed., New York, Modern Language Association of America, 2016, p. 100-101).

15. There is an additional, even more subtle tug of memory affectively activated here. Of all the precious stones Shakespeare might have used to particularize this ring, the turquoise is especially apt owing to its signifying a kind of double alien nature, both Turk and Jew. The stone's very name bespeaks its Levantine associations: the Middle English turkeis is derived from the Old French pierre turquoise (feminine adjectival form) meaning "Turkish stone," so called for having been first brought to Europe from Turkestan. Additionally, this stone is associated with, because named specifically as being part of, the Jewish High Priest's breastplate (Ex. 28:19 and Ex. 39:12, [Geneva Bible, London, 1599]).

16. Of the many places in Shakespeare's plays where a similar tug of memory gives stunning if tantalizingly vague insight into a character's backstory, few can match Lady Macbeth's "I have given suck, and know / How tender 'tis to love the babe that milks me" (Mac. 1.7.54f.). Cf. Emma Smith, This is Shakespeare, New York, Pantheon Books, 2019, p. 250-251.

17. Desiderius Erasmus, Adages Ii1 to Iv100, Collected Works of Erasmus, ed. R. A. B. Mynors, trans. Margaret Mann Phillips, Toronto, University of Toronto Press, 1982, p. 83-84.

18. See Lynn Enterline, Shakespeare's Schoolroom: Rhetoric, Discipline, Emotion, Philadelphia, University of Pennsylvania Press, 2012, p. 85-93.

19. Endel Tulving. "Ecphoric processes in episodic memory," London, Transactions of the Royal Society B302, 1983, 361-371.

20. J. L. McClelland, B. L. McNaughton, and R. C. O'Reilly, "Why there are complementary learning systems," Psychological Review 102.3, 1995, 419-457. This sort of memory recall is what neuroscientists mean by pattern completion.

21. George Puttenham, The Arte of English Poesie, London, Richard Field, 1598, STC ( $\left.2^{\text {nd }} e d.\right) 20519.5$, last accessed (via EEBO) 8 July 2020; on "paremia," see "Of figures and figurative speeches" (3.7); and on "copious amplification," see "A division of figures, and how they serve in exornation of language" (3.10) and "Of figures sententious, otherwise called Rhetorical" (3.19).

22. Verne R. Kennedy, "Auxesis: A Concept of Rhetorical Amplification," Southern Speech Communication Journal 37.1, 1971, 60-72, p. 60-64.

23. Alexander H. Sackton, Rhetoric as Dramatic Language in Ben Johnson (chap. 2 "The Tradition of Rhetoric"), $2^{\text {nd }}$ ed., New York, Octagon Books, 1967, p. 13.

24. Jane Baltzell, "Rhetorical 'Amplification' and 'Abbreviation' and the Structure of Medieval Narrative," Pacific Coast Philology 2, 1967, 32-39. 
25. Peter Mack, "The Classics in Humanism, Education, and Scholarship," ed. Patrick Cheney and Philip Hardie, The Oxford History of Classical Reception in English Literature, vol. 2, Oxford, Oxford University Press, 2015, 29-55, p. 33-40.

26. Patricia Parker, Shakespeare from the Margins: Language, Culture, Context (chap. 6, "Dilation and Inflation"), Chicago, University of Chicago Press, 1996, p. 216.

27. Virginia W. Callahan, "The De Copia: The Bounteous Horn," ed. Richard L. DeMolen, Essays on the Work of Erasmus, New Haven, Yale University Press, 1978, 99-109.

28. Enterline, op. cit., p. 134.

29. E. Ruth Harvey, The inward wits: Psychological theory in the Middle Ages and the Renaissance, London, The Warburg Institute, 1975, p. 58-60.

30. The English word "saws," denoting sayings from time immemorial, comes from the old English sagu, meaning to speak a speech; hence the term saga for an oral folk tale.

31. On the vogue of dramatic characters habitually given to sententiae, see Philip J. Finkelpearl, John Marston of the Middle Temple, Cambridge, MA, Harvard University Press, 1969.

32. Ann Moss, Printed Commonplace-Books and the Structuring of Renaissance Thought, Cambridge, Clarendon Press, 1996.

33. Fred Schurink, "Manuscript Commonplace Books, Literature, and Reading in Early Modern England," Huntington Library Quarterly 73.3, 2010, 453-469.

34. The phonetic substitution of " $p$ " for " $b$ " marking Fluellen's speech characterizes him as a recognizable, then topically humorous, stage stereotype of the hinterland Welshman, whose verbal tics portray him as a kind of ersatz English gentleman.

35. For an extended analysis of the name that eludes Fluellen - Sir John Falstaff - and what Shakespeare thereby is able to convey about the larger issue underlying the king's formerly having caroused with "the fat knight," see William E. Engel, "Handling Memory in the Henriad: Forgetting Falstaff," ed. Andrew Hiscock and Lina Perkins Wilder, The Routledge Handbook of Shakespeare and Memory, London, Routledge, 2017, 165-179.

36. None of the proverbs in the ensuing passage is attributable to any definite source, although printed compilations of such of proverbs were common in the period. See Sister Miriam Joseph, Shakespeare's Use of the Arts of Language, Philadelphia, Paul Dry, 2005, p. 98: "Proverbs or adages represent the testimony of many men; apothegms or maxims, often called sentences, the wisdom of one. The former, of popular origin, usually earn greater conviction, expressing as they do what generations have regarded as true."

37. Grace Ioppolo, Revising Shakespeare, Cambridge, MA, Harvard University Press, 1992, p. 1-18

38. Eric Griffiths, The Printed Voice, $2^{\text {nd }}$ ed. Oxford, Oxford University Press, 2018, p. 6.

39. On Renaissance rhetorical habits and the affective shaping of Shakespeare's characters, see Joel B. Altman, The Improbability of Othello: Rhetorical Anthropology and Shakespearean Selfhood, Chicago, University of Chicago Press, 2010, p. 235-260.

40. R. W. Dent, Shakespeare's Proverbial Language, Berkeley, University of California Press, 1981, p. 48

41. Randle Cotgrave, Dictionarie of the French and English tongues, London, Adam Islip, 1611, sig. Q2 $2^{\mathrm{v}}$, STC (2 ${ }^{\text {nd }}$ ed.) 5830, last accessed (via EEBO) 8 July 2020; see under the entry for Charrette, the idiom mangeur de charrettes ferrées: "A terrible cutter, swaggerer, bugbear, swashbuckler; one that will kill all he sees, and eat all he kills."

42. A commonly used structuring device in the period, see William E. Engel, Chiastic Designs in English Literature, New York, Routledge, 2016, p. 3-10, 130.

43. Francis Meres, Palladis tamia, Wits Treasvry, London, Cuthbert Burbie, 1598 , sig. Ii6 ${ }^{\text {}}$, STC $^{\left(2^{\text {nd }}\right.}$ ed.) 17834, last accessed (via EEBO) 7 July 2020. This is incidentally the same work, in another section on "Comparative Discourse," that first mentions Shakespeare favorably as the author of a dozen, specifically named plays.

44. Yates, loc. cit. 
45. Ann Blair, "Humanist Methods in Natural Philosophy: The Commonplace Book," Journal of the History of Ideas 53.4, 1992, 541-551, p. 541-544.

46. Francis Bacon, The Advancement of Learning, ed. Arthur Johnson, Oxford, Oxford University Press, 1974, p. 129.

47. Ágnes Juhász-Ormsby, “Erasmus' Apophthegmata in Henrician England," Erasmus Studies 37.1, 2017, 45-67, p. 47.

48. Erasmus, Adages, idem, p. 4.

49. Erasmus, On Copia of Words and Ideas, trans. Donald B. King and H. David Rix, Milwaukee, Marquette University Press, 2002, p. 11.

50. Morris Palmer Tilley, A dictionary of the proverbs in England in the sixteenth and seventeenth centuries, Ann Arbor, University of Michigan Press, 1950.

51. Although Erasmus gives examples of hundreds of ways to vary and ornament simple phrases (such as "thank you for your letter") in his pedagogical manuals, in his own writing he shunned periphrasis for fear of possible misinterpretation or overinterpretation; see Erika Rummel, Erasmus as a Translator of the Classics, Toronto, University of Toronto Press, 1985, p. 96.

52. This is the wording in French Huguenot Bibles printed in 1540, 1551, and 1556; and was "proverbial enough" to appear in Holinshed's Chronicle of Ireland (1587), p. 133, according to a note in William Shakespeare, Henry V, ed. Andrew Gurr, coll. New Cambridge Shakespeare, Cambridge, Cambridge University Press, 2012, p. 152.

53. John F. Tinkler, "Renaissance Humanism and the genera eloquentia," Rhetorica 5.3, 1987, 279-309, p. 283-286, p. 295-297.

54. Anny Crunelle-Vanrigh, “'Fause Frenche Enough': Kate's French in Shakespeare's Henry V," ed. Dirk Delabastita and Ton Hoenselaars, Multilingualism in the Drama of Shakespeare and his Contemporaries, Amsterdam, John Benjamins, 2015, 61-90, p. 79.

55. Patricia Phillippy, Shaping Remembrance from Shakespeare to Milton, Cambridge, Cambridge University Press, 2017, p. 100-103, p. 124.

\section{ABSTRACTS}

This study addresses the boundary between the stage and lived experience by focusing on evocations of prior histories of Shakespeare's characters. Taking the battle of wit carried out by means of commonplaces and proverbs in Henry $V(3.7)$ as a focal case study, as well as considering other such telling moments in The Merchant of Venice, Antony and Cleopatra, Much Ado, Hamlet, Cymbeline, and Henry $V$, my investigation offers a viable approach to staging the presentation of characters' backstories. My goal is to recover and comment on a set of principles for understanding one of the chief ways in which the shakespearean text is set up to guide both affective and expressive interpretation of characters. More broadly, this paper involves larger questions of how memory shapes identity, including the forging of memorable moments within the given performance reflecting normative stage business and other embodied forms of intertheatricality. This essay demonstrates how attention to the playwright's well-placed and condensed seeds of discourse-like proverbs themselves-unfold to convey whole histories and thus a backlog of information that can aid in audience understanding of characters' interactions that motivate stage activity as well as advance the plot arc. The critical insights brought out in this essay, concerning mnemotechnical cues and declamatory triggers to conjure plausible 
backstories leading to incipient action in the world of the play, can be used to explore more purposefully the built-in possibilities for moving a Shakespearean text from page to stage.

Cette étude porte sur la frontière entre la scène et le vécu en se focalisant sur les évocations de l'histoire antérieure de personnages shakespeariens. Prenant la lutte d'esprit sous forme de proverbes dans Henry $V$ (3.7) comme étude de cas, mon enquête offre une approche viable aux dramaturges et aux metteurs en scène de représentations scéniques et cinématographiques pour signaler à leurs comédiens et acteurs-et, par extension, au public-des moments où les tiraillements de la mémoire sont activés à l'intérieur du texte. Plus globalement, cette étude aide à cerner la question plus large de comment la mémoire est modelée et exprimée dans des productions théâtrales et filmées, y compris la mise en oeuvre de moments mémorables dans la représentation scénique ou dans la version filmée elle-même - et, en outre, les manières dont ils font allusion à la visualisation d'une oeuvre quant à sa présentation à travers le temps, et de même pour d'autres manifestations “d'inter-théâtralité." Spécifiquement, les aperçus critiques ressortant de cet essai (concernant des codes mnémoniques et des déclencheurs déclamatoires pour invoquer des trames de fond menant à une action dramatique naissante dans le monde de la pièce) aideront ceux qui contribuent à la représentation théâtrale à explorer de manière plus constructive les possibilités de transporter le texte shakespearien de la page à la scène.

\section{INDEX}

Mots-clés: Mots clés: études de la mémoire, histoire de la scène, proverbes, rhétorique, Shakespeare

Keywords: Keywords: memory studies, proverbs, rhetoric, Shakespeare, stage history 